\title{
Beberapa Inspirasi untuk Mengkaji Praktek-Praktek Konservasi Tradisional
}

\author{
Mahirta \\ Departemen Arkeologi, Fakultas Ilmu Budaya, Universitas Gadjah Mada \\ Email:mahirta@ugm.ac.id
}

\begin{abstract}
Indonesia memiliki tradisi yang kaya dan panjang dalam praktik konservasi tradisional baik preventif dan konservasi aktif. Praktek-praktek tersebut juga merupakan bagian dari warisan budaya takbenda dari Indonesia, sehingga harus didokumentasikan dan dipelajari secara ilmiah. Tujuannya tidak hanya untuk melestarikan budaya intangible itu sendiri tetapi juga untuk mengembangkannya sehingga praktik dapat diterapkan di dimanapun tanpa diragukan lagi karena efektifitas dan efek budaya materi telah dipelajari berdasarkan penelitian ilmiah. Artikel ini memberikan beberapa latar belakang dan inspirasi untuk memulai studi tersebut. Disarankan bahwa dokumentasi praktek-praktek tradisional harus dilakukan dengan hati-hati dan terperinci karena ada indikasi bahwa praktek hanya bagian dari seluruh proses holistik tidak akan menghasilkan hasil yang memuaskan.
\end{abstract}

Kata kunci: praktek tradisional konservasi, pelestarian preventif, konservasi aktif, inspirasi

\begin{abstract}
Indonesia has rich and long tradition of traditional conservation practices consisting both preventive and active conservation. Such practices, which are also part of intangible of cultural heritage of Indonesia, should be documented and studied scientifically. The purpose is not only to preserve the intangible culture itself but also to develop it so that the practices can be applied everywhere in the world without doubt because the efectiveness and effects to the material culture have been studied based on scientific research. This articles give some backgrounds and inspirations to start such studies. It is suggested that the documentation of traditional practices should be carried out carefully in details since there is indications that practising only part of the whole process holistically will not produce a satifying result.
\end{abstract}

Keywords: traditional conservation practice, preventive conservation, active conservation, inspiration

\section{A.Pendahuluan}

Berbeda dengan pengetahuan dan praktekpraktek tradisional di bidang pengobatan tradisional timur telah lama menarik perhatian dan diakui ketangguhannya oleh dunia barat, praktek-praktek tradisional timur di bidang konservasi budaya materi baru meningkat popularitasnya akhir-akhir ini di kalangan konservator beraliran barat. Sebelumnya, praktekpraktek konservasi budaya materi secara tradisional timur hanya cukup diketahui saja oleh para konservator beraliran barat dan kurang dipercaya keberhasilannya, meskipun telah dipraktekkan selama beberapa generasi di tempat asalnya. Praktek-praktek konservasi budaya materi secara tradisional ini sekarang bahkan menjadi tidak dikenal lagi oleh para konservator lokal di tempat asalnya, karena para konservator profesionalnya hanya mendapatkan kesempatan mengikuti pelatihanpelatihan dan pendidikan konservasi berbasis aliran barat. Dikhawatirkan pengetahuan konservasi tradisional ini menjadi punah, sebelum pemilik tradisi tersebut sempat menggali, meneliti dan menyempurnakannya. Sudah saatnya kita giat mempelajari kembali teknikteknik konservasi tradisional yangkita miliki dan mengembangkannya sesuai dengan perkembangan sains dan teknologi.

ICCROM sebagai organisasi tingkat dunia di bidang konservasi dan restorasi benda-benda budaya telah memberi perhatian pada cara-cara konservasi tradisional dalam bentuk mengakomodasi penelitian mengenai praktek-praktek konservasi tradisional di berbagai belahan dunia, misalnya di Afrika yang diterbitkan dalam buku berjudul "Trend of Concervation practices in Africa”(2005). Selain itu sejak tahun 2013, organisasi di Asia Tenggara: Korean Cultural Heritage Administration (CHA) telah memberi dukungan kepada ICCROM untuk menyelenggarakan kegiatan dengan fokus Pengetahuan Tradisional dan prinsip-prinsip sains dalam Konservasi (Traditional Knowledge and Scientific Principle in Conservasion). Kedua organisasi ini mengundang peneliti dari Asia Tenggara untuk magang dan menawarkan program 
felowship untuk malakukan kajian-kajian konservasi tradisioal untuk merawat hasil budaya materi.

Bagaimana tanggapan kita sebagai para peneliti Indonesia dan profesional konservator yang bekerja di museum tentang munculnya trend di dunia untuk melihat kembali konservasi yang dipraktekkan di dunia timur? Sebagai negara yang kaya dengan praktek-praktek konservasi tradisional, tentunya kita berkeinginan untuk mengembangkan metode konservasi tradisional yang kita miliki agar lebih berguna untuk melestarikan warisan budaya. Dengan melakukan kajian/penelitian di bidang konservasi tradisional berarti kita juga ikut melestarikan unsur budaya intangible Indonesia.

Meskipun niat untuk melakukan kajian/ penelitian tentang pelaksanaan cara-cara konservasi tradisional sering kali tertunda karena kurangnya inspirasi dari mana kita akan memulainya. Artikel inimenjabarkan pengertian konservasi menurut konsep timur dan barat dan memberikan beberapa inspirasi awal untuk mulai meneliti praktek-praktek konservasi tradisional yang dipraktekkan di Indonesia. Selanjutnya diperlukan pengujian-pengujian secara ilmiah agar dapat ditentukan keampuhan hasilnya sehingga praktisi di bidang pengelolaan warisan budaya tidak ragu-ragu lagi untuk menerapkannya

\section{B. Pengertian Konservasi Menurut Konsep Timur dan Barat}

Ketika kita menyebut praktek-praktek konservasi tradisional sering sekali dihubungkan dengan dikotomi adanya perbedaan antara konsep konservasi tradisional dan konsep konservasi modern, yang tidak sepenuhnya benar. Misalnya dikotomi adanya perbedaan fokus bahwa konservasi idea (isi) lebih penting di dunia konservasi tradisional (timur) dibandingkan pada konservasi material di dunia konservasi modern. Konservasi idea yang tersimpan dalam budaya materi, misalnya naskah lontar, memang menjadi tujuan utama untuk dilestarikan agar generasi mendatang mengetahui pesan yang disampaikan. Oleh karena itu, pada saat-saat tertentu dilakukan pembacaan naskah lontar secara berkelompok, agar pesan dalam naskah lontar tetap dapat diingat. Namun demikian, tindakan mengkonservasi naskah lontar secara fisik bukannya diabaikan.

Naskah berbahasa Jawa kuna yang menyebutkan dengan jelas adanya proses mengkonservasi idea/pesan yang disampaikan dari naskah yang tertulis pada lontar adalah naskah kakawin Sumanasantaka yang ditulis oleh pujangga Kediri, ditulis dalam bahasa Jawa kuna oleh Mpu Monaguna pada abad ke-13. Naskah ini beredar di Jawa pada masa lampau, dan sampai sekarang masih dijumpai di Bali. Metode konservasi idea yang terkandung dalam naskah Sumanasantaka dilakukan dengan menyalin naskah lama, dilakukan oleh seorang gadis yang bernama Ni Pangkajawatidari Pasandipura, Lombok yang mencatat dengan cermat tanggal mulai dan menyelesaikan penyalinan naskah. Terdapat juga nama penyalin penyalin sebelumnya yaitu Yagonada dan Kusapatra(Worsley, et. al. 2014: 25-26).

Di samping praktek konservasi berupa penyalinan naskah, dikenal pula diusaha-usaha pengawetakan material naskah lontar secara fisik dengan berbagai cara tradisional yang telah dilakukan secara berabad-abad. Berdasarkan komunikasi pribadi dengan Dr. Kartika Setyawati (5 Agustus 2014) terdapat bekas-bekas hangus pada bagian luar naskah lontar dan tepi-tepinya, memberi indikasi bahwa telah dilakukan pengasapan, kemungkinan untuk menjaga naskah lontar agar tetap kering, tidak lembab. Kesimpulan ini didukung dengan adanya profesi yang berkaitan dengan aktivitas pengkonservasian lontar di Bali sampai saat ini.

Pendokumentasian tentang tindakan mengkonservasi lontar di Bali dengan berbagai bahan tradisional (minyak cengkeh, minyak sirih, dan minyak kemiri dan campuran dari bahan-bahan tersebut) telah dilakukan.Cara-cara dan bahan-bahan yang dipilih telah digunakan berabad-abad, tetapi pengujian keampuhannya secara ilmiah baru dilakukan akhir-akhir ini. Berdasarkan studi eksperimen yang dilakukan oleh Sacara, ditemukan bahwa penggunaan minyak kemiri tidak efektif merawat lontar, bahkan menimbulkan potensi tumbuhnya jamur (Sacana, 2013), padahal praktek mengoles naskah lontar dengan kemiri secara empiris telah dilakukan selama berabad-abad.

Studi eksperimen yang dilakukan Alit Sacana masih dalam uji laboratoris, yang menguji penggunaan masing-masing bahan atau campuran beberapa bahan dalam satu macam kegiatan, sedangkan dalam praktekpraktek konservasi tradisional dilakukan beberapa kegiatan yang tidak hanya memakan waktu satu hari 
saja, tetapi sebagai satu rangkaian kegiatan berhari-hari yang menentukan hasil akhirnya. Oleh karena itu dalam mendokumentasi praktek-praktek konservasi tradisional perlu untuk mendokumentasikan semua kegiatan secara teliti, karena pada hakekatnya rangkaian kegiatan yang dilakukan merukakan kesatuan yang holistik. Uji coba yang telah dilakukan oleh sacana ini bisa membuka peluang agar penelitian tersebut dilanjutkan dengan membandingkan hasil pengolesan minyak kemiri pada daun lontar apabila mengikuti semua tindakan konservasi secara tradisional secara utuh dalam satu rangkaian dan apabila tidak mengikuti semua proses konservasi secara utuh. Penelitian dengan topik konservasi tradisional ini juga membuka peluang agar penelitian ini dapat dilanjutkan secara multidisiplin.

Selain dikotomi model konservasi barat dan timur yang dijelaskan di atas, terjadi juga kurangnya pemahaman mengenai rangkaian praktek-praktek konservasi tradisional di dunia timur yang dianggap kurang memberikan penekanan pada konservasi preventif. Sebenarnya konservasi tradisional di dunia timur juga diawalidengan konservasi preventif sampai dengan perawatan dari kerusakan yang dikenal dengan konservasi aktif dan restorasi. Waterson (1990: 87) mengidentifikasi bahwa desain lumbung padi di Kalimantan Timur telah menerapkan gagasan konservasi preventif: diletakkan di daerah yang tinggi dan di luar desa untuk menghindari kebakaran dan banjir. Selain itu, atap tritisan pada lumbung padi dapat dipindah sehingga dapat disesuaikan kegunaannya sesuai dengan arah angin ketika hujan. Krepp berpendapat bahwa sistem ventilasinya berfungsi untuk mengatur temperatur di dalam lumbung dan beroperasi seperti sistem pengontrol iklim. Bentuk atap dan bahan yang dipilih juga membantu ventilasi, cocok untuk diterapkan di lokasi beriklim lembab dan tropis(Krepp, 2011: 461).

Penanganan hama juga telah diterapkan pada arsitektur lumbung, yaitu dengan mengaplikasikan papan lempeng bundar pada tiang, sehingga mencegah tikus masuk ke dalam lumbung (Krepp, 2011:461). Pengaplikasian papan lempeng bundar dan persegi pada tiang bangunan tradisional, terutama lumbung seperti itu juga banyak diterapkan di lumbung-lumbung di Nusa Tenggara dan di Jawa Barat, sedangkan pada lumbung padi gaya tongkonan di Toraja, struktur untuk mencegah tikus menaiki tempat penyimpanan berbentuk papan persegi yang letaknya sekitar $50 \mathrm{~cm}$ dari permukaan tanah.

\section{Faktor-faktor yang Berpotensi Merusak Benda Budaya}

Untuk dapat melakukan konservasi benda budaya dengan baik harus difahami faktor-faktor yang kemungkinan dapat merusakatau menurunkan nilai benda-benda tersebut yang dikenal dengan "Ten Agents of Deterioration" seperti yang telah diusulkan oleh Michalski, 2014 yang dimuat dalam website Canadian Conservation Institute (CCI), yaitu:
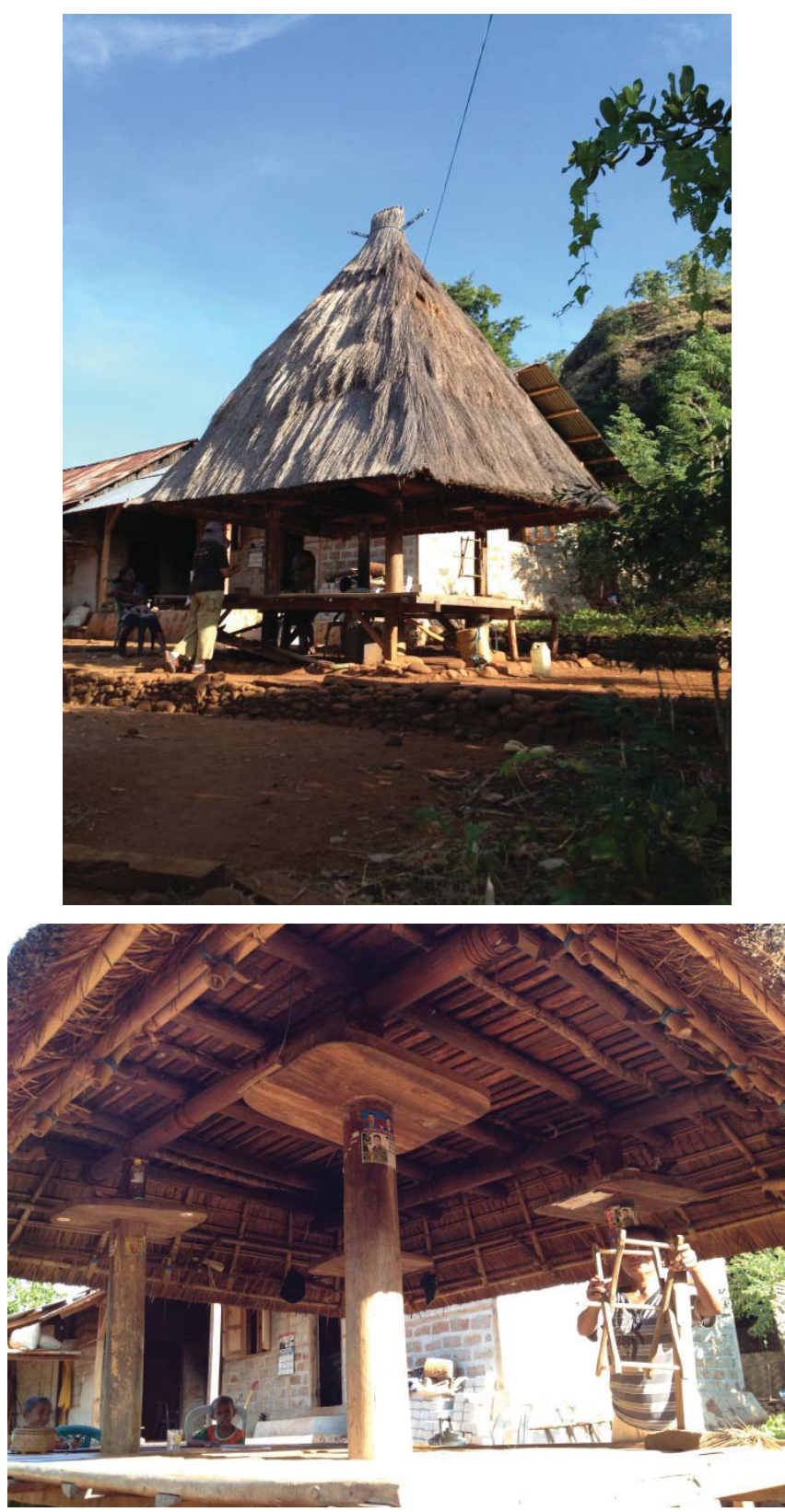

Gb 1. Bangunan tradisional di P. Alor. Struktur tiang dilengkapi dengan lempengan kayu berbentuk persegi untuk mencegah tikus naik ke atap tempat penyimpanan jagung 
1. Kekuatan fisik.

2. Pencurian dan vandalisme.

3. Disosiasi.

4. Api.

5. Air.

6. Hama.

7. Polutan.

8. Cahaya.

9. Temperatur yang tidak tepat

10. Kelembaban relatif $(R H)$ yang tidak cocok dengan benda, yaitu kelembaban relatif yang terlalu tinggi dan atau fluktuasi kelembaban yang telalu besar.

(Canadian Conservation Institute, 2014)

Berkaitan dengan lokasi geografis Indonesia, diantara sepuluh faktor perusak tersebut di atas,ketiga faktor utama yang merusak benda budaya di Indonesia adalah hama, temperatur, dan kelembaban yang tidak tepat. Ketiga faktor ini saling terkait, dan jika ketiganya terakumulasi menyebabkan proses kerusakan benda atau penurunan nilai yang semakin cepat. Faktor perusak utama berikutnyaadalah cahaya. Tampaknya, faktorfaktor perusak utama ini telah dapat diidentifikasi oleh nenek moyang kita secara tradisi, terbukti dengan adanya praktek-praktek untuk menyimpan benda yang difokuskanuntuk menghindari kerusakan dari pengaruh iklim (kelembaban dantemperatur), hama, dan cahaya. Faktor perusak utama inilah yang akan disinggung, berkaitan dengan beberapa praktek-praktek konservasi tradisional yang akan dijelaskan di bawah.

\section{Beberapa Sumber Inspirasi untuk Mengkaji Praktek-Praktek Konservasi Tradisional}

\section{Sumber naskah}

Naskah-naskah kuno yang dimiliki Indonesia sangat banyak. Naskah kuno berbahasa Jawa menurut Girardet (1983), dalam Marsono (2009) di museum Sonobudoyo saja tersimpan 1300 naskah, di Pura Pakualaman tersimpan 300 naskah dan di perpustakaan Pura Reksa Kraton Mangkunegaran tersimpan 500 naskah. Naskah-naskah tersebut diduga memuat berbagai kearifan lokal atau praktek-praktek tradisional dalam berbagai aspek kehidupan, diantaranya yang berhubungan dengan perawatan lingkungan, pusaka dan konsevasi benda pada umumnya. Karena merupakan bagian dari cerita, sebagian petunjuk-petunjuk tersebut sering kali disebutkan secara sambil lalu, disebutkan sebagai pantangan-pantangan (Bima, komunikasi pribadi, 4 Agustus 2014), tetapi ada pula yang disebutkan secara khusus dan mendetail, seperti misalnya dalam serat Centini, yang digubah dalam bentuk tembang (Marsono, komunikasi pribadi, 4 Agustus 2014).

Serat Centhini ditulis pada tahun 1814-1823, oleh tim penulis Adipati Anom Amangkunegara III, Putera Mahkota Kerajaan Surakarta. Kandungan teks Serat Centhini meliputi berbagai aspek kehidupan, yaitu sejarah, geografi, arsitektur, pengetahuan alam, dunia flora, obat tradisional, seni (suara, karawitan, tari, padalangan, dan topeng), tata cara "slametan" sesuai daur hidup, etika dan, sifat-sifat kemanusiaan. Karena lengkapnya, serat ini disebut oleh Adisasmita sebagai ensiklopedi Kebudayaan Jawa.

Pada Serat Centhini (Suluk Tambangraras) pupuh 223 yang dituliskan dalam tembang Dhandhanggula terdapat petunjuk yang berhubungan dengan kayu yaitu uraian mengenai asal usul pembangunan rumah berbahan kayu, macam-macam rumah berbahan kayu, cara memilih kayu dan ketepatan penggunaaan kayu jati yang berjumlah 11 macam, jenis-jenis kayu jati yang dihindari pemakaiannya, cara-cara penebangan kayu jati, cara-cara dan macam-macam sirap, ragam-ragam sambungan kayu, nama dan jenis sambungan kayu serta penguncinya, empat macam golongan atap rumah (joglo, limasan, kampung, mesjid), dan perbedaan bentuk-bentuk atap rumah (Adisasmita, 1975:32). Yang menarik dari hasil ringkasan yang ditulis oleh Adisasmita (1975) mengenai pemilihan kayu jati adalah telah diketahuinya hubungan antara jenis jati unggul sesuai dengan lingkungan tumbuhnya. Jati kualitas terbaik bila tumbuhnya di lahan bertanah merah dan kering. Di samping itu telah diketahui pula apabila pada pohon jati telah terdapat sarang burung, kemungkinan kualitasnya menurun atau kurang bagus. Hal ini menunjukkan bahwa hubungan antara sarang burung yang mengandung protein dan bakteri dari kotoran burung dengan merebaknya hama yang merusak kayu telah dikenal sejak dahulu.

Sumber-sumber tertulis mengenai praktekpraktek konservasi secara preventif merupakan bahan menarik untuk dikaji kebenarannya secara ilmiah. Sangat besar kemungkinannya pada setiap etnik di 
Indonesia memiliki kearifan lokal yang berhubungan dengan pemakaian dan pemanfaatan sumber daya yang berasal dari lingkungan sekitarnya sebagai bahan untuk konservasi preventif dan konservasi aktif yang termuat dalam naskah-naskah kuno. Hal ini perlu dikaji dengan cermat, karena tindakan konservasi yang dimuat dalam naskah tersebut, seringkali hanya disebutkan sebagai pantangan-pantangan, disebutkan sambil lalu sebagai bagian dari cerita, tidak secara langsung menyebutkan tujuannya untuk mengkonservasi.

Saat ini berdasarkan studi ilmiah yang telah dilakukan, Canadian Conservation Institute, mensosialisasikan tindakan konservasi preventif berupa aktivitas manajemen hama terpadu (Integrated pest management:IPM) untuk melindungi benda-benda budaya dengan berpedoman pada protokol "avoid, block, detect, respond, recover', yaitu rangkaian aktivitas terkontrol untuk menghindari, menghambat, mendeteksi, merespon dan memperbaiki kerusakan akibat adanya hama yaitu mikroorganisme, serangga, tikus, burung dan kelelawar. Meskipun tidak secara langsung merusak benda budaya organik, keberadaan sarang burung di ruang-ruang museum mengharuskan staf museum lebih waspada terhadap adanya kerusakan benda-benda karena serangga (Strang, Tom and Kigawa, Rika. 2009). Selanjutnyakelima protokol konservasi untuk menangani hama secara terpadu tersebut sebaiknya dilakukan dari lapisan terluar lokasi benda budaya (halaman sekitar dan gedung tempat penyimpanan). Hanya membasmi hama yang melekat langsung benda/ hasil budaya materi tanpa melakukan pengawasandan perbaikan koondisi pada lingkungan sekelilingnya tidak akan memecahkan masalah hama dalam jangka panjang. Gedung yang bocor, lokasi pembuangan sampah yang terlalu dekat dengan gedung dan tidak dibuang secara teratur, dan banyaknya banyaknyanya remah-remah makanan akan memicu datangnya hama dan selanjutnya akan menyebabkan terulangnya kerusakan pada benda budaya. Jaditindakan konservasi atau restorasi yang hanya dilakukan pada benda budayanya saja dengan melakukan konservasi aktif akan kurang bermanfaat tanpa melakukan konservasi preventif secara tersistem.Bahkan dalam waktu tertentu proses kerusakan karena hama akan berulang kembali.

\section{Tradisi lisan yang diwariskan dan didokumentasikan}

Dari tradisi lisan yang didokumentasikan dalam bentuk tulisan yang saat ini tersimpan di kraton, seperti Kraton Mangkunegaran, kita juga memperoleh beberapa petunjuk bahwa konservasi preventif tidak hanya dipraktekkan oleh model konservasi barat saja tetapi telah lama dipraktekkan secara turun temurun di lingkungan Kraton Mangkunegaran, Surakarta. Dalam kitab Bauwarna Wayang yang dihimpun oleh R.M.Sajid (1958), terdapat pedoman bagaimana cara konservasi preventif sampai dengan tindakan restorasi yang sebaiknya dilakukan pada koleksi wayang kulit.

Deskripsi langkah-langkah konservasi dimulai dari merawat kotak wayang, tata cara penataan wayang ketika mengangin-anginkanyang dimulai dari mengeluarkan, menggantungkan wayang-wayang pada tali, sampai dengan memasukkan kembali pada kotak wayang, tata carapembersihan kotak wayang, dan caracara pembersihan dan merawat wayang dari jamur bila jamur yang dibedakan apabila jamur yang menempel tipis dan apabila jamur yang menempel tebal. Dideskripsikan juga agar setiap dua minggu sekali atau sebaiknya daur tindakan konservasi preventif tersebut dilakukan sepuluh hari sekali pada musim hujan (rendheng) dan satu bulan sekali pada musim kering (katiga). Lokasi tempat pengisisan wayang juga telah ditentukan yaitu di ruang tengah pendapa sehingga terhindar dari cahaya matahari langsung (Sajid, 1958).

Agar terhindar dari kerusakan akibat kelembaban peletakannya harus sekitar $50 \mathrm{~cm}$ dari atas lantai, dan diletakkan di atas dua bangku panjang, ditempatkan tidak menempel pada dinding, sekurang-kurangnya $30 \mathrm{~cm}$ dari dinding (Sajid 1958:7). Wayang-wayang yang digantungkan dengan posisi yang sudah ditentukan, wayang-wayang kecil diletakkan di bagian tengah, untuk menghindari tali penggantung putus karena beban berat di bagian tengah tali penggantung. Setelah diangin-anginkan, sebelum dimasukkan dilakukan pengecekkan tali-tali yang longgar dan ada tidaknya jamur dan cat-cat yang mengelupas. Pembersihan dari jamur dilakukan tergantung dari kondisi tebal tipisnya jamur yang menempel. Jika tipis cukup dibersihkan dengan cara mekanik, yaitu dengan sikat halus. Indikasi jamur tipis, jika dilihat warnanya dari 
kejauhan tampak buram (klawus) (Sajid, 1958:14). Jika jamur yang menempel cukup tebal, dilakukan beberapa tahap yaitu pembersihan dengan kain lunak yang dibasahi dengan air hangat, kemudian dikeringkan. Jika setelah kering, warna tidak terlihat terang, proses pembersihan dengan kain lunak diulang lagi. Jika diidentifikasi catnya telah terlihat tua, wayang disiram dengan ancur lempeng/ ancur kripik ( merupakan campuran okker dan putih telur) yang dicampur dengan air landa jangkang .Setelah disiram dengan larutan ancur lempeng, warna akan terlihat mengkilat kembali. Jika warna telah mengelupas, warna yang tidak rata dikelupas kemudian diberi pewarna baru (Sajid, 1958: 15).

Jika kita amati secara keseluruhan dokumen perawatan wayang yang dihimpun oleh R.M.Sajid ini sangat lengkap, dimulai dari cara-cara pencegahan kerusakan (yang merupakan konservasi preventif) sampai dengan restorasi/perbaikan kondisi apabila wayang telah terserang jamur yang dapat diidentifikasikan sebagai konservasi aktif pada model konservasi barat.

Masih banyak lagi tradisi lisan yang dimiliki oleh bangsa Indonesia yang berhubungan dengan konservasi. Di antara tradisi -tradisi lisan tersebut banyak yang belum didokumentasikan seperti halnya yang telah termuat dalam Bauwarna Wayang. Di antaratradisi lisanmengenai konservasi yang telah didokumentasikan dan dikaji secara ilmiah adalah pemaikain campuran cengkeh, tembakau dan air batang (debog) pisang oleh masyarakat Kudus untuk mencegah kerusakan kayu oleh serangga (Mahirta, 2011; 85-99; Parwoto dan Arif Gunawan, 2010: 20-33).

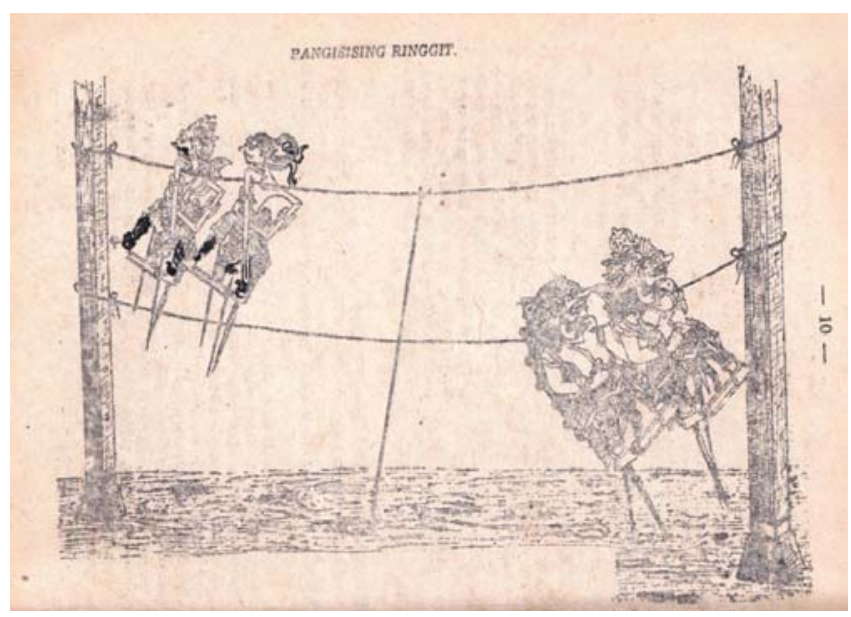

Gb.2. Cara mengangin-anginkan wayang yang dipraktekkan di Kraton Surakarta, yang didokumentasikan dalam kitab "Bauwarna Wayang" oleh R.M Sajid, 1958 (repro hlm.10)

\section{Inspirasi dari tradisi pengobatan tradisional}

Meskipun tampaknya tidak berhubungan langsung dengan konservasi benda, tradisi pengobatan tradisional di Jawa juga merupakan sumber inspirasi yang berguna untuk mencari bahan penelitian untuk mengembangkan konservasi tradisional. Macammacam pengobatan tradisional juga terdapat dalam serat Centhini. Beberapa diantaranya masih diterapkan dalam tradisi budaya Jawa sampai sekarang. Bahan-bahan yang dipakai sebagai obat tradisional yang berasal dari umbi-umbian, daun-daunan, dan rempah-rempah telah diketahui khasiatnya untuk menyembuhkan penyakit.

Berdasarkan kemampuannya untuk menghambat serangga, terutama nyamuk dan menyembuhkan bengkak akibat bisa gigitan serangga kita mengenal minyak serai. Apakah minyak serai dapat digunakan untuk mengkonservasi benda? Berdasarkanhasil penelusuran pustaka mengenaiminyak serai, ternyata keampuhan minyak serai telah banyak diteliti oleh peneliti. Ekstrak minyak serai (Pectis brevipeduculata) berdasarkan hasilpenelitian merupakan antimicroba, diantaranya terhadap jamur Candida albican(Marques, et. al. 2013). Minyak serai telah digunakan di Bali untuk mengawetkan naskah lontar. Ternyata kemampuannya tidak hanya menghindarkan serangan rengat. Kandungan minyak serai yang digunakan di Bali kemungkinan juga dapat menghambat pertumbuhan jamur (Sacana, 2013). Keampuhan kandungan ekstrak serai wangi,Cymbopogon nardus, yaitu serai yang tumbuh di Indonesia terhadap jenis-jenis jamur yang tumbuh pada benda budaya (lontar, kain, kulit wayang) perlu mendapatkan perhatian dari peneliti.Penelitian yang telah dilakukan dapat dilanjutkan agar memungkinkan kandungan minyak serai tidak meninggalkan noda minyak apabila disemprotkan pada benda budaya, atau menjadikannya dalam bentuk benda padat yang menguapkan aroma untuk mengusir serangga sehingga dapat diletakkan di sekitar benda budaya yang perlu dihindarkan dari gangguan serangga.

Selain daun serai, bahan yang umum dipakai di kalangan masyarakat Jawa untuk menghilangkan jamur pada kulit, seperti misalnya panu adalah dengan bawang putih. Kita juga mengetahui adanya praktek pemakaian bawang putih di Jawa untuk mencerahkan warna pada wayang kulit, yang lebih tepatnya sebenarnya adalah menghilangkan jamur pada wayang. Pengujian kandungan 
ekstrak bawang putih untuk menghilangkan jamur yang bersifat patogenik telah dilakukan oleh Tedhesci, et. al (2011). Oleh karena itu untuk meneliti secara lebih serius praktek efektivitas konservasi tradisional pada wayang kulit yang dilakukan, khususnya yang menggunakan bawang putih, diperlukan pula penelitian terhadap jenis jamur yang tumbuh pada wayang kulit, dan kemudian diikuti dengan pengujian tingkat kesensitifan jamur tersebut terhadap variasi kepekatan larutan ekstrak bawang putih. Aroma menyengat bawang putih merupakan salah satu unsur pengganggu, terutama apabila diterapkan pada benda budaya. Aroma tersebut dapat pula mengundang hama terutama kecoa untuk datang mendekat dan akhirnya menyebabkan benda tersebut rusak karena noda yang disebabkan oleh sekresi dan gigitan kecoa.Teknologi saat ini sangat memungkinkan untuk menghilangkan aroma bawang putih yang justru akan menarik kecoa untuk datang. Namun demikian,kemungkinan proses penghilangan jamur dengan bawang putih akan lebih berhasil jika dalam penerapannya dilakukan sebagai bagian dari rangkaian proses konservasi secara utuh seperti proses konservasi wayang yang telah dipraktekkan di Kraton Surakarta. Di Kraton Surakarta tersebut konservasi preventif telah dipraktekkan berabad-abad dengan mengangin-anginkan wayang secara berkala dan menghindarkan lokasi wayang dari kelembaban akibat kapilerisasi dinding ruang penyimpan akan mengurangi resiko datangnya serangga.

Umbi-umbian lain yang telah dimanfaatkan secara tradisional untuk memerangi jamur adalah lengkuas dan kunyit. Kandungan minyak lengkuas cukup jernih, sehingga mengurangi resiko munculnya noda jika diterapkan pada benda budaya dan aroma yang tidak menyengat pada lengkuas merupakan potensi bahan konservasi tradisional yang menjanjikan untuk dikembangkan. Penelitian ilmiah yang telah dilakukan memberikan petunjuk bahwa campuran ektraklengkuas dan mikroorganisme yang hidup berinduk pada umbi tersebutlah yang menyebabkannya efektif sebagai anti jamur yang bersifat patogen.Potensi untuk meneliti keampuhan ekstrak lengkuas untuk menghambat pertumbuhan jamur-jamur pada benda budaya patut dikembangkan.

Dibandingkan dengan lengkuas, minyak kunyit juga sudah dikenal secara tradisi sebagai pengobatan untuk menghilangkan bakteri. Kandungan warnanya yang pekat dan meninggalkan noda yang sulit dihilangkan juga tampaknya bukan merupakan hambatan lagi berkat kemajuan teknologi dan ilmu pengetahuan saat ini untuk dikembangkan sebagai konservan. Kandungan ekstraknya sebagai fumigasi natural sangat ampuh membunuh serangga dapat dikembangkan jika akan dipakai pada gudang penyimpanan dan tidak menyentuh langsung benda budaya materi. Penelitian yang dilakukan oleh Tripathi et. al (2011) membuktikan bahwa campuran ekstrak cardamon, kunyit dan jahe merupakan bahan ampuh untuk mematikan beberapa serangga yang hidup di gudang makanan.

Dari penjelasan di atas kita pelajari bahwa beberapa bahan-bahan yang biasa digunakan dalam pengobatan tradisional di Jawa memiliki aspek ilmiah, dan karena ditujukan untuk pengobatan, kandungan ekstrak bahan-bahan tersebut juga telah diuji keampuhannya terhadap jamur yang bersifat patogen yang sebagian berbeda dengan jamur-jamuryang hidup pada benda budaya.Untuk keperluan penelitian konservasi tradisional, diperlukan terlebih dahulu identifikasi jenis-jenis jamur perusak yang hidup pada benda-benda budaya.Hal ini kemudian dilanjutkan dengan pengujian keampuhan ekstrak rempah-rempah atau umbi-umbianterhadap jenisjenis jamur yang telah teridentifikasi. Fumigasi natural yang dikembangkan akan pula memiliki nilai tambah karena lebih ramah lingkungan dan tidak berbahaya bagi manusia.

\section{Penutup}

Ketika melakukan penelitian padapraktekpraktek konservasi tradisional sebaiknya tidak hanya difokuskan pada tindakan perawatan pada jenis benda budaya secara langsung, tetapi sebaiknya diteliti pula bagaimana masyarakat melakukan aktivitas-aktivitas sehari-hari dan aktivitas-aktivitas ritual yang melibatkan benda budaya yang diamati. Dari mempelajari tradisi lisan yang didokumentasikan dan wawancara dengan nara sumber, ada hal yang perlu kita renungkan bersama. Kemungkinan aktivitas perawatan/ konservasi benda budaya dengan menerapkan teknik-teknik tradisional yang diterapkan saat ini tampak kurang berhasil karena sebenarnya ada rangkaian aktivitas konservasi yang tidak dilakukan secara sempurna dan layer-layer perlindungan 
di luar benda budaya tersebut masih belum diperhatikan.

Penelitian untuk mengkaji ulang praktek-praktek konservasi tradisional dengan metode ilmiah memerlukan kerjasama antar disiplin antar berbagai bidang ilmu. Dua naskah kuna yang sempat penulis baca terjemahannya memberikan inspirasi bagaimana memanfaatkannya untuk mengembangkan metode konservasi tradisional

\section{DaftarPustaka}

Adisasmita, ki Sumadi. 1979. Pustaka Centhini. Ikhtisar Seluruh Isinya. Yogyakarta: UP. Indonesia.

Krepp, Chrisitina. 2011. Non-Western Models of Museuma and Curation in Cross-Cultural Perspective dalam Sharon Macdonald (ed.).A Companion to Museum Studies. Oxford: Blackwell Publishing. hlm. 457-472.

Mahirta. 2011. Protection of Rumah Pencu in Kudus (Northern Central Java, Indonesia). Dalam Preservation and restoration of Wooden Structures. Training Course on Cultural Heritage Protection in Asia-Pacific Region 2011. Nara: Cultural Heritage Protection Cooperation Office, Asia-Pacific Cultural Centre for UNESCO (ACCU). hlm. 85-99.

Marsono, ed. 2009. Serat Centhini jilid V-XII. Yogyakarta: Fakultas Ilmu Budaya Jurusan Sastra Jawa.

Marques, Andre M et. al. 2013. Traditional Use, Chemical Composition and Antimicrobial Activity of Pectis brevipedunculata eEssencial Oil. A Correlatated lemmongrass Species in Brazil. Journal of Food Agriculture. Vol 25 (10): 798-808.

Michalski, 2014. Ten Agents of Deterioration.http:// www.cci-icc.gc.ca/fw/index.eng.aspx.

Parwoto dan Arif Gunawan. 2010. Pengujian Efektivitas Bahan Tradisional. Dalam Konservasi Cagar Budaya Berbahan Kayu dengan Bahan Tradisional. Magelang: Balai Konservasi Peninggalan Borobudur. hlm. 20-33.

Sacana, Ida bagus Alit. 2013.Kajian Efektivitas Teknik dan Bahan Konservasi pada Naskah Lontar di Bali. Tesis S2. Jurusan Arkeologi, Fakultas Ilmu Budaya, Universitas Gajah Mada.

Sajid, R.M. 1958. Bawwarna Wayang. Yogyakarta: 1958. di Indonesia dan kemungkinan masih banyaknya lagi kearifan lokal yang berhubungan dengan praktek konservasi tradisional yang belum dimanfaatkan saat ini. Bidang ilmu sastra nusantara, ahli kimia, arkeolog and antropolog sebaiknya bekerja sama dalam pengkajian bidang ini.

Strang, Tom and Kigawa, Rika. 2009. Combatting Pests of Cultural Property. http://www.cci-icc.gc.ca/crc/ fiv/index.eng.aspx.

Tadeschi, P., Leis, M., Pezzi, M, Civolani, S. 2011. Insecticidal Activity and Fungitoxicity of Plant Extracts and Component of horseradish (Armoracia rusticara) and garlic (Allium sativum). Journal of Environmental Science and Health, Part 3, vol 46: 486-490.

Tripathi, Arun K. Singh, Amil K. Upadhyay, Shika. 2011. Contact and Fumigants Toxicity of Some Common Species Against the Storage Insects Callosobrochus maculatus and Triboleum castareum. International Journal of Tropical Insect Science vol 29 no. 3: 151-157.

Worsley, P., Supomo, S., Flechert, M. 2014., Kakawin Sumanasantaka, mati karena bunga sumasana. Karya Mpu Monaguna.Jakarta: Ecole francise d'Extreme-Orient

\section{Narasumber:}

Dra. Kartika Setyawati, dosen Jurusan Sastra Nusantara, FIB, Universitas Gadjah Mada

Prof. Dr. Marsono, dosen Jurusan Sastra Nusantara, FIB, Universitas Gadjah Mada

R. Bima Slamet Rahardjo, S.S., M.A, dosen Jurusan Sastra Nusantara, FIB, Universitas Gadjah Mada. 